\title{
TRANSKULTURALNOST I KREATIVNOST
}

\section{Sažetak}

Digitalna forma dokumenta, slike, ili zvučnog zapisa čuva u širokom zamahu kulturološki, duhovni i nacionalni identitet kolektiva i pojedinca i omogućava međusobno upoznavanje naroda. Nova digitalna književnost, i digitalna humanistika, sa stalnim osloncem u društvenoj, književnoj i umetničkoj istoriji i estetici, jeste nova kreativna strategija savremene transkulturalnosti.

Ključne reči: transkulturalnost, kreativne strategije, nacionalni identitet, kulturna baština.

Glavni simboli savremenog doba postali su: pravovremena i brza informacija, implicitno koliko i eksplicitno znanje, kreativnost, konkurencija, multidisciplinarnost, kolaborativnost, fleksibilnost, minimalizacija grešaka, kao podloge za buduće znanje, intelektualna različitost, kompresija i vizualizacija velikog broja podataka. $U$ takvom društvu prateća pojava je masovna kultura, a s njom i trivijalna književnost, koja podržava zadovoljavanje potrebe za informacijom i zabavom, a da od čitaoca ne očekuje veliko znanje kao preduslov za razumevanje pročitanog. Najuspešnije knjige jesu upravo one koje uspevaju da spoje i pomire zahteve i umetničke i trivijalne književnosti. ${ }^{1}$ Veza umetničke i trivijalne književnosti nije u sistemu opštevažećih istina, ona zavisi od istorijske, personalne predmetnosti i relacija. Može se postaviti i pitanje: Da li je trivijalna književnost odgovor na krizu čitanja? Da li su potrebni iracionalizam, misticizam, fan-

1 Vujin, Bojana. Načini prevazilaženja klišea trivijalne književnosti u Dnevniku Bridzet Dzouns Helen Filding. Polja. God. LII. Br. 445. Maj-jun 2007. 
tastika i idealizam da bi se izbegla pusta faktografija svakodnevice, da bi se udovoljilo istovremeno minimalizovanim estetskim potrebama i poštovala vremenska oskudica? Pitanja o smislu ili besmislenosti ljudske egzistencije zahtevaju, istina, i racionalno promišljanje, ali im je nužno potreban i emocionalni i estetski odgovor, makar i u formi trivijalne književnosti.

Umetnički fenomen u celini, prema tome i proces stvaranja i doživljavanja, svagda je jedinstvo trojakog uticaja: civilizacijsko-istorijskog, kulturno-istorijskog i individualno-psihološkog činioca. Iz toga, apstraktno posmatrano, sleduju: estetsko-humana, istorijsko-kulturna i lična vrednost u tvorevini, u doživljaju i u kreativnom procesu.

lako, verovatno, svi autori književnih dela teže stvaranju kantovskog „lepog" i „uzvišenog“, njihova tvorevina katkad zastaje na nivou prijatnog, utapajući se u književnost kratkog daha i efemernog duha, udovoljavajući duhovnim potrebama i emocionalnim prohtevima šire čitalačke publike, koja uživa u stečenoj oblasti „zasićenog zadovoljstva“ Ludviga Gica. Sociološki podsticaj je uticao na oblikovanje čitalačkog ukusa publike, kao i na nastanak „krize samog estetskog fenomena“. Objašnjavajući trivijalnu književnost primenom sociološkog metoda, Nada Vučković zaključuje: „Trivijalna književnost se širi i razvija pojavom masovnog društva. $U$ vreme velikih socijalnih prestrukturiranja, kada je povećana ekonomska individualna i kolektivna nesigurnost, pokazuje se težnja da se, ako već nije moguć povratak u dobra stara vremena, učvrsti i osigura postojeći poredak. Jedan od važnih instrumenata je masovna kultura, i trivijalna književnost kao njen bitan deo. Konzervativnost na ideološkom planu time se prenosi na književni. Odnosi koji iz toga proizlaze posledica su uticaja društva na književnost i obratno." Snaga trivijalne književnosti nastaje iz činjenice da ona zadovoljava kolektivne duhovne potrebe društvene zajednice u određenom vremenu. Ukoliko tih potreba ne bi bilo, nestala bi i trivijalna književnost. ${ }^{2}$

Realnost socijalnog života u Japanu značajno je različita od evropskog okruženja. Kao poseban oblik trivijalne književnosti razvija se japanski roman o radnom čoveku, takozvanom sararimanu, koji treba da svome junaku pomogne da dostigne unutrašnju harmoniju, da živi s nadom i dostojanstvom u društvu koje ga sputava i sapliće svojim, iz prošlosti

2 Damrosch David, (2003). What Is World Literature Princeton and Oxford: Princeton University Press,. 
nasleđenim, normama. Jasno definisani profili junaka romana, u kojima se mogu prepoznati arhetipovi, svojstveni japanskoj dramaturškoj tradiciji, događaji i tabui kojima je uokviren život sararimana u japanskim paternalističkim kompanijama, besprekornost ličnog i porodičnog života, prvorazrednost obrazovanja, ponašanja, karijere, načela konfucijanstva životni su i pripovedački kodeks japanskog popularnog romana. ${ }^{3}$

Na pozornici japanske literature zapaženo mesto ima Ihara Saikaku (1642-1693), koga danas smatraju velikim romanopiscem, dok ga neki kritičari stavljaju čak odmah posle autorke prvog japanskog romana, dvorske dame Murasaki. Iharini radovi su proučavani i priređivani isto onako kao što su tretirana klasična dela čiste književnosti, tako da postoji veliki broj zapisa o njihovoj strukturi, skrivenim značenjima i odnosu prema tadašnjem društvu. Svakako da bi Saikakua takva pažnja prenerazila da je kojim slučajem mogao da je doživi jer su njegovi radovi, u pravom maniru trivijalne književnosti, isporučivani na tržište čim bi ih on ispisao, i to onako na brzinu, bez ikakvog razmišljanja o tome šta će budućnost ili književna kritika o tome reći. ${ }^{4}$

Saikakuov prvi roman Život jednog raskalašnog čoveka (Koshoku Ichidai Otoko 好色一代男) objavljen je krajem 1682. godine. U to vreme Saikaku je već bio poznat kao jedan od najvećih pisaca haiku (俳句) poezije. Posle smrti Nišijame Soina (西山宗因), te iste godine, Saikaku je bio popularniji nego bilo koji drugi pesnik škole Danrin (談林), a svoju popularnost krunisao je naredne godine - 1684, kada je u hramu Sumijoši Taiša (住吉大社) zadivio svet nezaboravnom predstavom, posle čega je dobio nadimak „Majstor 20 hiljada stihova“. Međutim, Saikaku je postao poznat $\mathrm{u}$ istoriji književnosti perioda Tokugava po tome što je stvorio novi žanr trivijalne književnosti. Bile su to Priče o lebdećem svetu (Ukiyo zoshi 浮世 草子) koje su opisivale ljubavne doživljaje, bilo u javnim kućama, ili u okviru života trgovaca, o čemu i prva reč prvog Saikakuovog romana Košoku govori. Bukvalno značenje ove reči je koji voli ljubav, a odnosi se na veoma razuzdanu osobu. Ovaj termin ukijo označava lebdeći svet zadovoljstava (a ne tužni svet), što je homonim ove reči značio u srednjovekovnoj književ- 
nosti. Reč ukijo je poprimila izrazito erotske tonove, a drvorezi ukijo, kao pratilac ovih romana, otpočeli su kao pornografske slike.

Život jednog razvratnog čoveka zadobio je popularnost kod široke čitalačke publike kao roman s erotskim sadržajem. On nije pornografski, jedino se za jedan Saikakuov rad može reći da predstavlja pornografiju, a u njemu se do detalja opisuju putovanja i dogodovštine čoveka koji je voleo ljubav, i to od detinjstva, od sedme godine starosti, sve do šezdesete godine, kada je odlučio da otplovi na ostrvo na kome su živele samo žene. Ovaj roman je podeljen u 54 poglavlja, od kojih svako odgovara po jednoj godini života glavnog junaka Jonosukea. Broj poglavlja, koji je isti kao i broj poglavlja u romanu Genđi monogatari, sugeriše, po mišljenju mnogih kritičara, Saikakuovu nameru da parodira, ovog svog velikog književnog preteču. Svakako da je Saikaku, pišući prvi roman svoga doba, tražio inspiraciju u prvom japanskom romanu Genđi monogatari, pa je i usvojio njegov čuveni obrazac u kome se opisuju ljubavni doživljaji jednog jedinog glavnog junaka. Međutim, kako je Saikaku stvarao romane trivijalne književnosti, sve se Jonosukeu (世之介) dešava na površinskom nivou - on ne oseća takva razočarenja u ljubavi koja bi ga navodila na razmišljanja o smislu života, ili o "tuzi stvari“ (mono no aware), tako da su njegovi odnosi sa ženama opisani jednostavno kroz brojne ljubavne poduhvate, a ne kroz dubine njegovih osećanja ili kroz način kako ga je osvojila svaka od tih žena. Jonosuke nam se samo ponekad čini ljudskim bićem u punom smislu te reči, najveći deo vremena on provodi kao neumorno oružje požude koje do kraja ne saznaje ništa više o ženama nego što je znao još u detinjstvu, čak i posle bezbroj obljuba koje je postigao koristeći se ličnim šarmom i obilnim trošenjem novca. On postoji samo u okvirima ove jednoznačne opsesije. Ne uočava se nikakav razvoj njegove ličnosti. S gledišta književnosti ovaj roman je bez ikakve vrednosti. Priča je nepovezana, bez odgovarajuće strukture, dok je junak papirna kreacija koja teško da se može pohvaliti ijednom dublje analiziranom ljudskom osobinom, međutim, u pravom maniru trivijalne književnosti, ovaj roman je predstavljao ogroman uspeh u drugim pogledima. Jonosuke je odmah zadobio popularnost kao osoba koja oličava težnje novog društva, koja poput Robinzona Krusoa predstavlja junaka koji razvija svoje sposobnosti; „čoveka sveta lebdećih zadovoljstava“, sveta slatke neizvesnosti, zadovolj- 
stava i uvežbavanja pesnika. Ne samo da je ovo prvi roman novog žanra srednjovekovne trivijalne književnosti već je i Jonosuke nova vrsta heroja. ${ }^{5}$

Mnogi kritičari su tumačili njegove romane kao slavospeve novoj kulturi, koja je odbacila tmurnost srednjeg veka i šuplju didaktiku žanra kana zoši. Smatraju da je Saikaku pisao „za zabavu, ako ne jednostavno samo za pare." Trivijalni aspekti Saikakuovog opisa u ovom njegovom prvom romanu evidentni su od samog početka i kulminiraju njegovim krajem, usmerenim na nepresušnu prirodu fizičkih zadovoljstava koje je pisac nagovestio već u prvoj rečenici romana. Elementi trivijalnosti su sasvim jasni, kao i površinski karakter obrade događaja, likova i motiva, komercijalna usmerenost i apelovanje na najbanalnije ljudske strasti, takođe i zabavni karakter ovog štiva. Komercijalni uspeh rada potvrđuje rasprodate izdanje iz Osake i pojava "divljeg“ izdanja u Edu (koje je ilustrovao poznati slikar Hishikava Moronobu 菱川 師宣). Sve je to uticalo na Saikakua da se odluči da postane profesionalni romanopisac. ${ }^{6}$

Saikakuov realizam je veoma udaljen od realizma evropskog romana XIX veka. On je takođe veoma različit od realizma njegovog savremenika, dramskog pisca Ćikamacua, čiji je romantični ton u oštrom kontrastu sa Saikakuovim nedostatkom osećajnosti. Ćikamacu je opisivao prostitutke i kurtizane romantično kao žene koje je neka nužda naterala da se bave ovom profesijom, želja da pomognu starim roditeljima, ili nešto slično, ili kao osobe koje odlikuje velika iskrenost, koju pokazuju kada neretko prate u smrt svoje ljubavnike (vršeći „dupla samoubistva“). Kada uporedimo način opisivanja javnih kuća Ćikamacua i Saikakua, jasno se vidi da je Ćikamacu realističniji u insistiranju na tome da je prodaja ženskog tela u suštini odbojna. On je takođe realističniji jer evocira muke ljubavi. Saikakuovi junaci provode živote u vođenju fizičke ljubavi, ali je čoveku poput Jonosukea svaka žena gotovo identična. Čak i žene koje umiru iz ljubavi ne preživljavaju kod Saikakua ništa od one smese radosti i tuge koja prati ljubav, već doživljavaju isključivo fizička zadovoljstva.

Saikaku je veoma uspešan u korišćenju humora. Komične efekte postiže tako što nabraja, izuzetno precizno, neke nevažne objekte ili događaje iz gradskog života koje realistično i oštroumno beleži. I u situacija- 
ma koje bi u normalnim uslovima zahtevale romantičnu napetost, Saikaku insistira na zdravom razumu, pa i na taj način postiže komične efekte. Na primer, bačvar obećava provodadžiki koja njegova osećanja treba da prenese voljenoj Osen ( Nare (奈良), drugog kvaliteta“, pri čemu ovo drugog kvaliteta predstavlja takav elemenat preciznosti i prisustva zdravog razuma da se čitalac mora nasmejati. Odmah posle toga Saikaku kaže: "Ovo je zapalilo vatru u srcu bačvarevom koja je tada gorela još većom žestinom, te on uzviknu: 'Gospo moja, obezbediću te $s$ dovoljno drva da imaš da kuvaš sebi čaj celog života!'“ Poenta je u tome što zaljubljeni bačvar, čak ni u najvećem emocionalnom žaru, ne propušta da se ograniči na „,količinu drva koja je potrebna za kuvanje čaja", a ne ni u kom slučaju za količinu drva koja je uopšte potrebna u životu, te se tako unapred obezbeđuje od prevelikih obaveza prema gospi kojoj se udvara. Saikaku to potcrtava sledećim komentarom: „Na ovom svetu niko ne zna koliko neko drugi može da poživi, i zanimljivo je to što ga je ljubav naterala da obeća čak i toliko mnogo za toliko dugo". Ovakvu vrstu humora primećujemo i kod Genđija Keite, koji s neobičnom preciznošću naslovljava jedan od svojih najpoznatijih romana Zamenik direktora trećeg ranga, pri čemu je treći rang svakako element koji čitaoca drži sa stalnim osmehom na licu tokom čitanja čitavog romana. ${ }^{7}$

U 20. veku delima Saikakua, po osećaju za svakodnevicu i popularnosti među čitaocima, pariraju dela Genđi Keite (富山), čije je pravo ime Tanaka Tomio (田中 富雄). Dobitnik je i značajne nagrade u oblasti trivijalne književnosti, nagrade Naoki (Naoki- šō 直木賞). Budući da trivijalna književnost uživa ogromnu popularnost kod čitalačke publike Japana, kao i da je uspela da održi tradicionalno veoma cenjeno mesto u okviru literature, nagrada Naoki predstavlja značajno književno priznanje koje se dodeljuje kao pandan Akutagavinoj nagradi (Akutagawa- šō 芥川賞) za najbolji roman ili priču u oblasti tzv. čiste književnosti.

Središnjim delom izuzetno bogatog opusa Genđija Keite smatra se već pominjani roman Zamenik direktora trećeg ranga (Santō Juyakū 三 等重役). Slede ga: Srećković (Kofuku-san 幸福さん), Devojka suncokreta (Himavari musume 向日葵娘), Službenik - mamin sin (Botchan-shain 坊ちゃん社員), Carstvo Pacifika (Miran Svet) (Tenka taihei 天下泰平),

$7 \quad$ Konishi Jin-ichi. (1991), Nhihon bungei shi, vol.5 Kodansha: Tokyo. 
Srećni praznik (Taian Kichijitsu 大安吉日), Živeo šef (Shachō Banzai社長 万歳), Priča o prvoj ljubavi (Hatsukoi monogatari 初恋物語), Marunoući centar Tokija (Tokyō Marunouchi 東京丸の内), Ispunjena Želja (Taigan đođu 大願成就); Najusamljeniji čovek u Tokiju (Tokyō-ichi Sabishii Otoko 東京一淋しい男), Stolica zamenika direktora (Jūyaku no isu 重役の 椅子), Oblak koji plovi (Nagareru Kumo 流れる雲), Ošin (Oshin おしん), Dugme i maramica (Botan to hankachi ボタンとハンカチ) i mnogi drugi. U kratkim pričama i romanima Genđi Keita opisuje mnoge dogodovštine i tabue koji karakterišu život savremenog japanskog čoveka. Po mišljenju književnog kritičara Hasamija Ensana, brojne su zabrane koje vladaju životima zaposlenih u japanskim paternalističkim kompanijama. Hasami kao najučestalije naglašava zabranu ljubavi između zaposlenih u istoj kompaniji, zabranu sklapanja braka sa ženama koje rade u kafanama ili barovima i svaku zabranu bilo kakvog drugog „nedoličnog“ ponašanja mladih radnika u sferi njihovog ličnog života. Pisac verno prenosi radnu klimu i međuljudske odnose $u$ japanskoj firmi i jasno ukazuje na pravu prirodu „paternalističke“ brige koju u svim detaljima kompanija „vodi“ o svojim zaposlenima. To je tako verno ogledalo japanskog društva da sami Japanci ne mogu da odole a da ne čitaju o sebi, odnosno da ne čitaju knjige u kojima nalaze utehu od svojih svakodnevnih opsesija i frustracija na do tančina regulisanom radnom mestu - utehu koja je to, makar i samo zato, što im jasno govori o rasprostranjenosti tih muka koje ih svakodnevno pritiskaju. Japanskom radnom čoveku lakše je kada zna da se i svi drugi japanski radni ljudi izlažu istoj vrsti torture svakog dana kada pređu preko praga svoje firme.

Jedna od najčešćih tema iz kruga maltretiranja zaposlenih svakako je i veliko mešanje kompanije, odnosno poslodavca, kroz figuru neposrednog šefa, u izbor bračnog druga. Genđi Keita je sve to dobro znao jer je dvadeset pet godina radio u Kompaniji Toa Zaibacu i na sopstvenoj koži iskusio veliki deo svega onoga što opisuje kao dogodovštine svojih mnogobrojnih junaka. Zato je s toliko snage i uverljivosti opisao svet radnog čoveka koji se nije ni u čemu bitnije izmenio do kraja njegovog života (umro je 13. septembra 1985. godine).

Posle Drugog svetskog rata došlo je do raspuštanja velikih koncerna Zaibacu, ali Genđi verno opisuje kako su ovi koncerni samo izmenili spo- 
ljašnje ruho, a zadržali gotovo netaknute sve odlike odnosa među ljudima na radnom mestu. I on je sam posle rata zauzimao vrlo visok položaj u firmi Sumitomo, tako zaodenutoj u novo ruho. Najveći broj zapleta svojih romana Genđi je našao upravo u ovim godinama svoje karijere. $U$ isto vreme, duboko je shvatio i ružnoću ljudskog egoizma koji se, koristeći se hijerarhijskim odnosima u japanskoj kompaniji, ispoljava u svom najgorem svetlu i čini ionako teške i opsesivne uslove rada u japanskoj firmi još težim. Ovaj angažovani pisac hladno i s analitičke distance, a u isto vreme i veoma vešto i umešno, daje detaljan prikaz svih važnijih formi ugrožavanja slobode ličnosti koje se sreću u životu japanskog radnog čoveka, pri čemu je uvek nedvosmisleno na strani ugnjetenog i izmučenog sararimana. Treća velika odlika Genđijevih romana jeste, da se poslužimo rečima kritičara Komatsua Šinrokua (小松 伸六), pravilno shvatanje iskrivljene ljubavi i lojalnosti prema kompaniji, i suviše strog odnos prema neposrednim pretpostavljenima, koji često dovodi do svoje suprotnosti. To je najbolje prikazano u Genđijevoj kratkoj noveli Đavolji šef (Oni-kachō 鬼課長). Šefovi strahovito kritikuju i strogo vaspitavaju tek zaposlene pojedince. S druge strane, nalaze se tzv. Hotoke-kacho (仏課長), odnosno božji šefovi koji predstavljaju drugu moguću krajnost blagonaklonog diktatora, punog razumevanja za potčinjene. Treća vrsta bio bi idealni šef, koga svi japanski zaposleni priželjkuju, ali je to san koji se teško ostvaruje u čitavoj šumi isprepletanih rigoroznih pravila i propisa života i rada u japanskoj kompaniji. Opisujući strogost đavoljeg šefa, blagonaklonost božjeg šefa i nedostižnost idealnog šefa, Genđi daje izuzetno dobru sliku najskrivenijih želja i potreba sararimana, bilo da se ovaj nalazi u ulozi tek zaposlenog pripravnika, bilo da je i sam u veoma formalnom položaju šefa. Genđi uvek koristi istančani smisao za humor opisujući zgode i nezgode sararimana, te nam se čini kao da njegov izvanredni duh govori kako se pakao života sararimana ipak može prevazići. Kritičar Komacu kaže da piscu u ovom prevazilaženju pomažu duboka humanost i vera u to da se odnosi među ljudima mogu i moraju graditi na fleksibilnijim osnovama. Ove karakteristike stila Genđija Keite prožimaju sva njegova dela i postavljaju temelje jedinstvenosti njegovog pristupa problematici posmatranja radnog konteksta u savremenom Japanu.

U japanskom društvu i njegovoj konfucijanskoj tradiciji mesto ratničke klase samuraja u društvenoj hijerarhiji, u procesu modernizacije i 
industrijalizacije zemlje, dodeljeno je novoj elitnoj klasi - poslovnim ljudima, upravljačima i radnim članovima japanskih kompanija - koji se svi jednim generičkim terminom nazivaju sararimani. Sarariman, bukvalno čovek koji živi od svoje plate, predstavlja savremeni ekvivalent samuraja koji je tokom čitavog srednjeg veka živeo od svoje „plate“ izražene u broju bačvi pirinča kojim ga je pretpostavljeni nagrađivao, ali je ta količina bila centralno utvrđena za svaki samurajski rang posebno. Striktno je bilo propisano koliko će bačvi pirinča (kokudaka 石高) pripadati kom samurajskom rangu, kao i koje druge monetarne (iskazane u naturi) oblike plaćanja će samuraj dobiti. ${ }^{8}$ Samuraji, sem samuraja najvišeg ranga, nisu poput evropskih feudalaca raspolagali zemljom na osnovu koje su sticali dohodak, već su, naprotiv, imali određen godišnji prihod iskazan u količini pirinča, što je tokom vekova, usled dinamičkog razvoja tržišno orijentisane proizvodnje i dugog mira dovelo do postepenog ali sigurnog siromašenja samurajskog sloja, usled nepovoljnih kretanja cena na štetu pirinča i drugih primarnih proizvoda. Držeći se veoma striktno načela „duh Istoka - tehnika Zapada“, očevi japanske modernizacije ugradili su sve bitne elemente samurajske etike, kao i načina nagrađivanja, u formiranje obrazaca života i rada savremene armije japanskih poslovnih ljudi kojima je zadatak bio da se bore za primat Japana, ali ovoga puta ne katanama (刀), već višom produktivnošću i savršenijom poslovnošću nego bilo ko drugi na svetu. Nenovčane naknade koje su samuraji primali kao dodatak plati izraženoj u pirinču imaju direktni ekvivalent u računima za reprezentaciju, igralištima za golf, „,katanama“, letovalištima, korišćenju automobila, telefona i svih drugih zamislivih pogodnosti firme koji se mogu odbiti od poreza, a koji, pored ogromnih viškova (bonus ボーナス), koje u zavisnosti od uspešnosti poslovanja firme dva puta godišnje zaposleni primaju u iznosu od čak i do pet mesečnih plata, svaki put predstavljaju elemente zasnovane na dugoj samurajskoj tradiciji, radi nastavljanja i procvata starog, feudalnog tipa međuljudskih odnosa i u savremenoj industriji i privredi. ${ }^{9}$ Tako se sarariman, ukoliko je srećan da dobije posao u nekoj od prvorazrednih velikih kompanija, doživotno vezuje za njenu sudbinu, dajući joj svu svoju odanost, baš onako kao što je u feudalnom, predmodernom periodu,

8 Levi-Strauss, Claude. (1952) Race and History. Paris: Unesco,.

$9 \quad$ Konishi Jin-ichi. (1991), Nhihon bungei shi, vol.5 Kodansha: Tokyo 
samuraj svaki delić svoga bića dugovao zapovedniku (kada bi zapovednik poginuo ili umro, pogotovo ako mu je pri tom naneta neka nedostojnost ili okaljana čast, onda bi se, u ekstremnim slučajevima, od njegovih podanika samuraja, kao i od njegove prve žene - honsai (本妻) - očekivalo da ga i oni prate u smrti, odnosno da svoju lojalnost dokažu time što neće ostati živi posle njega). ${ }^{10}$ Isto tako, savremeni sarariman deli sudbinu svoje kompanije do kraja: prvo, posvećuje celog sebe i sve svoje kako radno, tako i slobodno vreme i energiju za dobrobit kompanije. Genđi opisuje kako sarariman dolazi kući u kasne sate pošto je, posle desetočasovnog ili dvanaestočasovnog radnog vremena, još i svratio na piće sa šefom i kolegama, a kako i vikende, odnosno nedelje, pošto subotom inače uglavnom radi, mora da provodi igrajući golf, takođe sa šefom i kolegama; drugo, kako sve čini da bi njegova kompanija uspela u oštroj konkurentskoj borbi na domaćem i na svetskom tržištu, ne bi li ostvarila što bolje rezultate i što veći rast. Rad u većoj kompaniji sinonim je za veći društveni prestiž jer su i kompanije poput univerziteta, gimnazija, „nižih“ i „viših“ srednjih škola, osnovnih škola, pa čak i dečjih vrtića strogo hijerarhijski podeljene na „prvorazredne“, „drugorazredne“, "trećerazredne“ i one koje su ispod ovakvih kvalifikacija. Prvorazrednost se, prema tome, ne definiše isključivo u odnosu na veličinu jedinke, mada je ona garant istorije uspešnog rasta, jer izgleda da nigde kao u Japanu teorija o tzv. rastu firme, odnosno organizacione jedinice nije toliko svesrdno prihvaćena, niti je uzela toliko dubokog korena. Može se reći da je ideja suprotna Šumaherovoj malo je lepo u Japanu poprimila sva obličja harizmatičnosti, kao što je u Engleskoj viktorijanskog doba imala ideja progresa. Kao što su viktorijanci u doba gradnje i širenja Britanske imperije, u kojoj se, na jednom njenom kraju rađalo, a na drugom zalazilo sunce $u$ istom danu i $u$ istom času, verovali da čovečanstvo ide konstantnom uzlaznom linijom ka sve većem boljitku, što je kao nacionalno ubeđenje osnaženo i Darvinovim i darvinističkim teorijama, a potom i kod liberalnih članova ovog društva, dobilo podstrek Marksovom teorijom razvoja ljudskog društva, tako je i u Japanu dobro poznata činjenica da je samuraj u službi velikog feudalca bio daleko iznad samuraja u službi sitnog, da je njegov položaj bio zagarantovan i materijalno udoban, dok je samuraj u službi slabog zapovednika mogao i da se

10 Marković, Ljiljana. (2008). Novela o radnom čoveku. Beograd : Filološki fakultet 
nađe na ulici posle smrti, pogibije ili propasti svoga gospodara. Ovakva situacija je postajala sve učestalija u periodu Sengoku, u vreme feudalne anarhije i krvavih međusobnih obračuna feudalaca u borbi za prevlast i ujedinjenje Japana pod izvršnom vlašću - odnosno za zadobijanje carskog postavljanja u funkciju Seii Tai Soguna (征夷大将軍). ${ }^{11}$

U Japanu je, znači, pored feudalne lojalnosti u savremeni period i njegov sistem vrednosti ušla i duboko ukorenjena ako ne ideja „veliko je lepo", onda svakako makar ideja „veliko je sigurno i moćno“. I sam karakter japanske modernizacije koja je sprovođena "odozgo“ pomogao je da se održi ovakvo shvatanje hijerarhičnosti na osnovu moći, relativnog položaja i veličine koja se na taj način formira. Da je japanska revolucija izvedena odozdo, kao buržoaske revolucije u Evropi, onda bi svakako u japanskom društvu izbila na površinu ideja o tome da i oni koji u jednom periodu nemaju nikakvu moć ili veličinu mogu u sledećem da je steknu pomoću oružja i da se kola moći i veličine i te kako radikalno mogu preokrenuti. ${ }^{12}$ U Japanu, međutim, nikada u čitavoj istoriji potčinjeni i eksploatisani nisu uspeli da točak istorije okrenu na radikalan način u svoju korist makar u kratkom periodu. Ovde su se čak i revolucija i građanski rat odigravali radi ponovnog uspostavljanja carske vlasti i modernizacije zemlje i izvedeni su planski na osnovu svesne odluke vladajuće klase, ako ne i samog šogunskog klana, i ostali su kompletno u rukama vladajuće elite, odnosno velikih i moćnih. Otuda i tolika opčinjenost veličinom i moći, za koje Japanci duboko u podsvesti veruju da su „večne“ i nepromenljive. Uprkos budističkom verovanju da se sudbina stalno preokreće u svojim krugovima, što Japanci prihvataju kao načelo ličnog života, ovo budističko viđenje u svesti sararimana ne proteže se i na društvenu i političku sferu života, u kojoj su, inače, uvek vladala načela konfucijanstva. ${ }^{13}$

Potreba za jeftinom (u dvostrukom smislu jeftinom) obmanom, za iluzijom „iz druge ruke“ ostaće obeležje konzumiranja trivijalne književnosti do danas. U naše doba, dominantno obeležje svake književnosti koja negira trivijalnost, jeste njen otpor što joj pruža šablon rastvarajući obras-

11 Rene Wellek and Austin Warren, (1977). The Theory of Literature, Third Edition Harcourt Brace Jovanovich, New York.

12 Marković, Ljiljana. (2008). Novela o radnom čoveku. Beograd : Filološki fakultet

13 White, Hayden (1978). Tropics of Discourse - Essays in Cultural Criticism.: The John Hopkins University Press, Baltimore and London 
ce ili podvrgavajući kritici besmisao stereotipa. Po smislu i značaju ona je danas mnogo više upitna, nego li potvrdna vrednost, svakako odraz kulture i života jednog naroda.

\section{Literatura}

Damrosch David, (2003). What Is World Literature Princeton and Oxford: Princeton University Press,.

Fikfak, Jurij. (1980). Ideologija dr. romana. „Problemi“, 18, št. 197, str. 113-123

Fischer, Ludwig. (1976). Der Zweck und die Heilung der Mittel. Zur Bildung eines literarischen Kanons und zu seiner aktuellen Veränderung in Germanistik und Deutschunterricht. V: Ludwig Fischer (ur.): Gebrauchsliteratur. Stuttgart

Flessau, Kurt-Ingo. (1968). Der moralische Roman. Studien zur gesellschaftskritischen Trivialliteratur der Goethezeit. Köln - Graz

Fullerton, Ronald A. (1976/77). Creating a Mass Book Market in Germany: The Story of the 'Colporteur Novel'. „Journal of Social History“, 10, str. 265-283

Grafenauer, Ivan. (1943). Duhovna bramba in Kolomonov žegen. „Razprave Akademije znanosti in umetnosti“, I. Ljubljana, str. 201-339

Greenberg, Clement (1939). Avant Garde and Kitsch. V: Clement Greenberg: Art and Culture. Boston

Greiner, Martin. (1964). Die Entstehung der moderner Unterhaltungsliteratur. Studien zum Trivialroman des 18. Jahrhunderts. Reinbek

Gudelj, Jasenka (2005). Raccontare la Storia. La Sfida Narrativa di Luther Blisset/ Wu Ming di Luther Blisset/Wu Ming 2. Gianmario Guidarelli and Carmelo G. Malacrino. Storia e narrazione - Retorica, Memoria, Immagini. Bruno Mondadori:.Milano

Jerkov, Aleksandar. (1992). Tržište kao trivijalan izgovor. Nadređeni stv. nasl. O položaju knjige. Tekst ćir. Podlistak Polja. U: Polja. ISSN 0032-3578. God. 38, br. 397/398. Glasnik DKV. ISSN 1452-2195. God. 2, br. 6. str. 14

Jovićević, Tatjana. (1995). Istorijski roman kao vid trivijalne književnosti kod Srba u XIX veku U: Književna istorija. ISSN 0350-6428. God. 27, br. 97 str. 413-421

Yonnet, Paul. (1993). Voyage au centre du malaise francaie: L'antiracisme et le roman national. Gallimard,.: Paris.

Kolakowski,Leszek. (1986). Ou sontles barbares? Les illusions de l'universalisme culturel. Le Village introuvable. Trans. Jacques Devvitte, Editions Complexe, Paris

Kundera, Milan. (1985). Le livre du rire et de l'oubli. Trans. Francois Kerel: Gallimard, Paris. Konishi Jin-ichi. (1991), Nhihon bungei shi, vol.5 Kodansha: Tokyo.

Marković, Ljiljana. (2008). Novela o radnom čoveku. Beograd : Filološki fakultet

Taketori monogatari - The Tale of the Bamboo Cutter, Kodansha International Ltd., Tokyo, 1999

Levi-Strauss, Claude. (1952) Race and History. Paris: Unesco,. 
Rene Wellek and Austin Warren, (1977). The Theory of Literature, Third Edition Harcourt Brace Jovanovich, New York.

White, Hayden (1978). Tropics of Discourse - Essays in Cultural Criticism.: The John Hopkins University Press, Baltimore and London

\section{Ljlljana Marković \\ University of Belgrade \\ Faculty of Philology}

\section{TRANSCULTURALITY AND CREATIVITY}

\section{Summary}

The digital form of a document, image, or sound record preserves the cultural, spiritual and national identity of the collective and the individual and allows people to get to know each other. New digital literature, and digital humanities, with a permanent support in the social, literary and art history and aesthetics, are a new creative strategy of modern transculturalism. tage.

Key words: transculturality, creative strategies, national identity, cultural heri- 